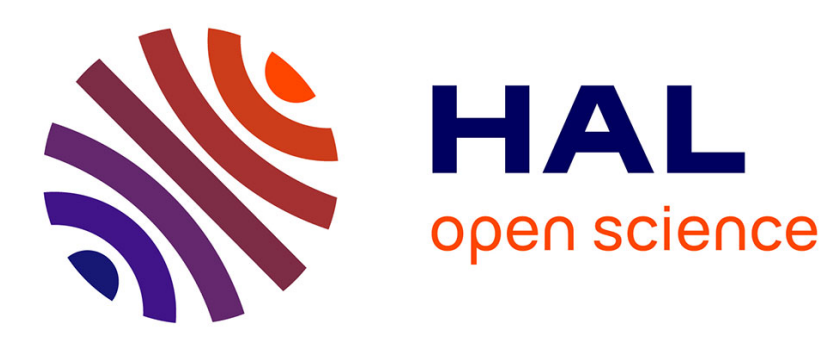

\title{
To Give or Not to Give? How Do Other Donors React to European Food Aid Allocation?
}

\author{
Nathalie Ferrière
}

\section{To cite this version:}

Nathalie Ferrière. To Give or Not to Give? How Do Other Donors React to European Food Aid Allocation?. European Journal of Development Research, 2022, 34, pp.147-171. 10.1057/s41287-02100360-w . hal-03166442

\section{HAL Id: hal-03166442 https://hal-amu.archives-ouvertes.fr/hal-03166442}

Submitted on 2 Feb 2022

HAL is a multi-disciplinary open access archive for the deposit and dissemination of scientific research documents, whether they are published or not. The documents may come from teaching and research institutions in France or abroad, or from public or private research centers.
L'archive ouverte pluridisciplinaire HAL, est destinée au dépôt et à la diffusion de documents scientifiques de niveau recherche, publiés ou non, émanant des établissements d'enseignement et de recherche français ou étrangers, des laboratoires publics ou privés. 


\title{
To Give or Not to Give? How Do Other Donors React to European Food Aid Allocation?
}

\author{
Nathalie Ferrière*
}

\begin{abstract}
Using a change in EU food aid policy in 1996 as an instrument for EU food aid allocation, I investigate how other donors react to the EU's food aid allocation. At that time, the EU suddenly divided by two the number of its food aid recipients. On average, other donors imitate the $E U$ at both extensive and intensive margins. Donors' reactions are heterogeneous: European countries and Canada herd the EU, while the World Food Programme substitutes. The US do not react. Those results can be explained by competition for relative impact and information effects. For a recipient country who constantly received food aid from the EU before 1996, the number of donors decreases by almost 0.5. This behavior reinforces the problem of orphan and darling recipients.
\end{abstract}

Keywords: Food Aid, European Union, Coordination, Interaction, Allocation

*Aix Marseille Univ, CNRS, AMSE, Marseille, France. and CHERPA EA4261, Institut d'Etudes Politiques, 25 rue Gaston de Saporta, 13625 Aix-en-Provence, France.

I thank the World Food Programme sharing for the data. The research leading to these results has received funding from the European Union's Seventh Framework Programme FP7/2007-2011 under Grant Agreement n290693 FOODSECURE. The author alone is responsible for any omissions or deficiencies. Neither the FOODSECURE project and any of its partner organizations, nor any organizations of the European Union or European Commission are accountable for the content of this paper. This work was supported by the French National Research Agency Grant ANR-17-EURE-0020, and by the Excellence Initiative of Aix-Marseille University - A*MIDEX. 


\section{Introduction}

In 2017, while the United States (US) provided more than 1.4 million MT of in-kind food aid valued at $\$ 1.7$ billion, they announced a reduction of about 32 percent of its food aid budget, asking other donors 'to do their fair share'. The leading donor expected others to substitute. However, some practitioners warned of a negative snowball effect, arguing that 'the U.S. government [...] catalyze contributions from other donors' (Nancy Lindborg). The way donors interact will critically affect the food supply for recipient countries. If donors imitate other donors, a decrease in food aid from one donor may lead to detrimental effects for health [Quisumbing, 2003]. While if donors tend to substitute, it mitigates the impact. It also affects the way donors can coordinate.

Three donors may particularly induce reactions because of their status and size: the US, the European Union (EU) and the World Food Programme (WFP). The EU is the second donor, providing about 10 percent of total food aid. EU member states add a further 10 percent through their bilateral program and are obviously influenced by the EU allocation, a point documented below. More importantly the EU is a key player on development and humanitarian assistance. It is reflected by the major role the EU played in the WFP since its creation even if it is not the largest contributor [Barrett and Maxwell, 2005]. Second it has been a leading component of the reforms of the Food Aid Convention (FAC) in 1999 and 2011 that promote a shift from food aid - driven by donors' surplus - to food assistance - driven by recipients' needs. Moreover, the EU was one of the first donor promoting innovative delivery systems such as local purchases. Finally, the EU provides an example of successful reform to disentangle agricultural policies and food aid policy conversely to the US. The WFP is the logistics leader on delivery and a coordination device and play a role of advocacy. All these aspects were awarded in 2020 by the Peace Nobel Price.

Many factors suggest that interactions among donors are likely to occur in the case of 
food aid even if food aid is seen by the general public as more humanitarian in nature and more oriented towards recipient needs than general ODA. Indeed it has already been shown that the allocation of food aid depends on donors' interests [Neumayer, 2005]. ${ }^{1}$ For instance in the late 1990s food aid delivery to North Korea was delayed to incite the regime to keep in peace negotiations. Food aid can be used to put pressure on recipients; hence it could also be a way to compete with or put pressure on other donors as ODA. Second the allocation of food aid is more publicized than for ODA: "when a state gives emergency food aid to starving people in another state, it rarely happens without notice and fanfare. [...] The ceremonies of this status demonstration include having as many witnesses as possible." [Aaltola, 1999]. Labels and emblems are clearly specified on food to enhance the identity of the donor - its flag on the rice bag for instance. In an individual context, Vesterlund [2003] shows that public announcements by some donors affect donations from others. The visibility of food aid donors increases the likelihood of having such strategic interactions among donors. In the Indian context, Besley and Burgess [2002] show that public food provision is more politicized than calamity relief and its provision depends more on political cycle because of the visibility factor. Third, the issue of coordination has emerged long before the 2005 Paris Declaration. The FAC in 1967 provided "a framework for cooperation, coordination and information-sharing among members to achieve greater efficiency". Hence given the historical background and the specificity of food aid relative to other types of aid, it seems more likely to observe strategic interactions between food aid donors than in other types of aid. At least one case of strategic interaction has already been documented by political scientists. Kim [2011] investigates how China and the US allocate food aid to North Korea and show that they strategically react to each other because they compete for leadership in this geographical area.

Many studies examine food aid allocation in general [Zahariadis et al., 2000] and show high persistence in the allocation of aid but few articles discuss donors' interactions. 
Kuhlgatz et al. [2010] simultaneously estimate food aid allocation for various donors and allow correlations among donors. They interpret the positive correlation as a sign of donors acting jointly. However, donors may react to each other for reasons than aid coordination. The empirical literature on donor interactions in the case of ODA is vaster but remaining limited. Frot and Santiso [2011], using methods from finance, show small but significant interactions - that they call "herding behavior": if a donor increases its aid, this results in a more than 1-for-1 increase for the recipient, as other donors step in. Fuchs et al. [2015] look at overlapping aid allocation that they interpret as a lack of coordination, given the risk of duplication.

Using panel data, Davies and Klasen [2019] find a small but significant positive effect of other donors' aid on the amount of aid provided by a particular donor. They carefully do not interpret their results as coordination. They also provide some rationale on what could generate positive or negative dependencies in donor allocations. Galiani et al. [2017] relies on an exogenously determined eligibility threshold based on concessionary International Development Association (IDA) loans. They find that bilateral aid is significantly reduced when a country crosses the cut-off. They also find large heterogeneity across donors, especially between EU member countries and non-EU countries.

This article provides new evidence of such behavior for food aid donors. Precisely, I estimate the causal effect of the EU allocation decision on the allocation of other donors at the extensive and intensive margins. The identification exploits the exogenous variation in the timing of the reform of EU food aid policy in 1996 to construct an instrument for EU food aid allocation. If the EU stops allocating aid to a recipient country, it decreases by 5.7 percentage points the probability of receiving food aid from another donor. However, donors are heterogeneous: the US and small donors do not react to the EU allocation. Canada with a relatively similar budget imitates the EU as well as European donors. Those effects can be explained by differences in budget size. 
Only the WFP substitutes the EU. Those results can be explained by competition for relative impact and information effects.

\section{Theoretical considerations}

Following the distinction between public good and private properties of aid [Mascarenhas and Sandler, 2006, Bourguignon and Platteau, 2015] and based on Annen and Moers [2016] theoretical framework, I develop arguments to assess how donors should react to the EU.

A donor who alleviates hunger through food aid provision cannot prevent other donors from benefiting, even if their participation is ineffective. As a classic consequence of public good provision, the allocation of food aid from one donor should lead to free-riding effects. The donor would stop its own allocation but obtain the benefits from the allocation of other donors. As a result, donors who only value public good aspects of food aid should substitute for the EU's withdrawal. The existing literature shows that bilateral donors favor private interests while multilateral donors focus more on recipients [Barrett and Heisey, 2002]. The first hypothesis is:

H1: As a multilateral donor, the WFP should substitute for the EU allocation.

Annen and Moers [2016] develop a model in which size matters because donors react to each other because their objective is to maximize the relative impact of aid. The best strategy for small donors is to substitute. They do not allocate aid to all recipients, unlike large donors. On the contrary for a large donor, if the budget size is similar to another large donor, the best strategy is to compete; hence to strategically complement the EU allocation. If the budget is higher, the donor will fragment its aid but do not consider the allocation from the other donors. The US is a large relative to the EU, Canada and Japan have a similar budget. Other donors are small donors. The second 
hypothesis is:

H2: If budget size is a major driver of donor interactions, the US should not react to the EU; Japan and Canada should imitate the EU while other donors should strategically substitute for the EU.

For European donors, information can fulfil a dominant role. The EU has larger capacities to conduct need assessment. They could interpret EU allocation as a signal for needs. This argument holds also for small non-European donors for whom information is relatively costly. In addition, information sharing within the EU is cheaper than between other countries because of the institutional framework. Hence,

H3: For EU members and small countries, the information effect can offset the size effect and lead to herding behavior.

Others donors may use food aid to secure an extensive list of private objectives leading to herding behavior: export promotion, diplomatic influence, labelling effect, need for visibility... The literature shows that some donors, such as France, the US and Germany, favor more such interests [Berthélemy, 2006] it should reinforce the herding effect. Some donors, such as Scandinavian countries, are looking for a good reputation [Gates and Hoeffler, 2004] mitigating herding effect by specializing on neglected recipients.

H4: The herding effect should be higher for Germany and France than for Scandinavian countries.

Finally donors may not react at all to the allocation of other donors if they are indifferent between public good and private aspects. 


\section{Empirical strategy}

\subsection{Data and Method}

Data come from the INTERFAIS database [WFP, 2011]. A food aid flow is defined by a donor $d$, a recipient $r$, and a year $t$. The sample is composed of 144 recipient countries between 1988 and 2011. I focus on donors which have allocated food to at least one recipient every year since 1988. This comes out to 21 donors (see table 5 for a list). They represent about 96 percent of total food aid. Regular donors are more likely to react to EU food aid allocation as food aid represents an established program. Here, EU food aid allocation is the one decided by the European Commission and does not include bilateral programs of EU member states.

Between 1988 to 2011, food aid quantities were divided by more than three, from 13.5 million tons of commodities to 3.6 million tons. Except the US for which we can observe a U-curved trend and the WFP that increased its aid, all donors decreased their aid. However, food aid remained an important source of food commodities for some countries like Ethiopia [Ferrière and Suwa-Eisenmann, 2015]. Additionally, projections on food security including climate change are quite pessimistic [WFP, 2017].

In this context, the EU has played a key role as a food aid donor. The EU is the second donor in the world after the US. In 1988, EU food aid represented almost 18 percent of global food aid. This share dropped to 10 percent in the 2000s. However, in the 2000s, 42 percent of recipients received food aid from the EU who is, in 68 percent of cases, among the top three donors.

Figure 1 provides the annual number of unique recipients by groups of donors: the EU, EU member donors, and non-EU member donors. Before 1996, the trend is similar. The EU experiences a specific pattern after 1996, with a sharp decrease in the number of food aid recipients which was divided by two. It is the consequence of the food aid 
reform I will present.

I investigate how donors react to EU food aid allocation controlling for other determinants like recipients' needs and geopolitical bilateral effects, $X_{r, t-1}$ and $X_{d r, t-1}$. I consider the following specification:

$$
F A_{d r t}=\beta F A_{E U r t}+X_{d r, t-1} \Gamma_{1}+X_{r, t-1} \Gamma_{2}+\phi_{d t}+\phi_{d r}+\epsilon_{d r t}
$$

The dependent variable, $F A_{d r t}$, is a dummy equal to one if the food aid allocated by donor $d$ reaches recipient $r$ at time $t$. $F A_{E U r t}$ is a dummy equal to one if the EU food aid reaches recipient $r$ at time $t . \phi_{d t}$ and $\phi_{d r}$ are fixed effects.

I focus on the $0 / 1$ decision to give rather than on quantities because it is easier for a donor to anticipate whether the EU will allocate food aid to a recipient, rather than the exact amount delivered especially for in-kind aid. Next, I look at quantities.

Allocation decisions are often announced before food aid reaches the recipient country. Donors are more likely to react promptly to this type of announcement rather than once food aid has been distributed. Thus, I use the contemporaneous EU allocation rather than that of the previous year. ${ }^{2}$

Controls are lagged to consider the time required to deliver aid. The decision is more likely based on past needs. I control for population size, domestic grain production per capita, and GDP per capita. I introduce the share of refugees and internally displaced populations in recipient countries. I include a dummy equal to one if the recipient country suffered from a natural disaster at time $t-1$. In the case of a large-scale disaster, food aid delivery could be fast. Hence, I also introduce contemporaneous disaster. I control for conflict within the country and the number of contiguous conflicted countries. Many articles suggest the effectiveness of aid depends on the 
quality of the recipient country. Therefore, donors are more likely to allocate aid to countries with better institutions. Hence, I include a democracy index (Polity IV) and two indicators of civil liberties and political rights.

$X_{d r, t-1}$ represents a vector of time-variant variables specific to the donor-recipient pair capturing changes in the bilateral relationship which can affect the donor's willingness to give. The most critical factor is the type and quality of diplomatic relationships, proxied by the UN vote similarity index [Strezhnev and Voeten, 2012]. The allocation of food aid may depend on whether a donor delivers other types of aid like development aid. Thus, I include the current amount of ODA, excluding food aid. ${ }^{3}$ Table A.1 in Appendix A provides descriptive statistics of the control variables.

I allow time effects to differ across donors with donor-year fixed effects, $\phi_{d t}$ : this accounts for donor-specific trends in food aid budget or for electoral cycles that can affect the allocation of aid [Tingley, 2010]. Hence it captures specific donor trend in food aid allocation. $\phi_{d r}$ is the donor-recipient pair fixed effects that capture time-invariant specificities. For instance, ceteris paribus, France tends to allocate more food aid to former colonies.

Concerning the estimation strategy, I estimate the equation with a linear probability model with fixed effects. Indeed, the inclusion of donor-recipient fixed effects and time fixed effects is more important for the estimation strategy than the range of predicted values. Standard errors are clustered at the recipient and year level.

The coefficient of interest, $\beta$, is the estimated effect of food aid allocation by the $\mathrm{EU}$ in country $r$ on the probability of participation of donor $d$ in country $r$. F $A_{E U r t}$ is endogenous because of two problems: omitted variables and reverse causality. First, donors may react to similar shocks for which I do not have reliable data or which I do not observe at all. For instance, in 1984, the BBC launched a global media campaign to 
inform people about the famine in Ethiopia. In reaction, governments increased their food aid to Ethiopia. As I do not have reliable data on all media campaigns, I cannot control for these recipient-related common shocks.

Second, the EU itself may react strategically to the allocation of other donors. One could argue that using the previous allocation by the EU $\left(F A_{E U r t-1}\right)$ solves the problem of endogeneity. However, $F A_{E U r t-1}$ could still be endogenous in case of 'dynamics among the unobservables' as pointed by Bellemare et al. [2017]. If $F A_{E U r t-1}$ is correlated with the error term $\epsilon_{d r t-1}$ and shocks are auto-correlated, $F A_{E U r t-1}$ is still correlated with $\epsilon_{d r t}$. It is plausible as food aid allocation is quite persistent over time.

\section{$2.2 \quad$ Instrumental Strategy}

To provide causal evidence, I instrument the EU allocation using a natural experiment, which is a substantial reform of the EU food aid policy ratified in 1996. The identification strategy relates to Werker et al. [2009] and Nunn and Qian [2014].

Before 1996, EU food aid was supply-driven. Since 1967, EU food aid had been closely linked with the Common Agricultural Policy (CAP), both policies were related to European regulation. The primary purpose was to run down the agricultural surplus. Thus, the EU reaction to recipients' needs was slow [Clay et al., 1996], and food aid was allocated to numerous countries.

At the beginning of the 1990s, the EU progressively abandoned agricultural subsidies and target prices and purchases, causing a decrease in EU stocks in line with the negotiation of the Doha Round. So did food aid quantities. In parallel, the EU was criticized within the development assistance community for slowness and unpredictability of delivery. Hence, after the European Parliament election in 1994, the EU decided to launch an external evaluation of its food aid program. 
The evaluation was the primary source of recommendations for the reform which was adopted on June 27, 1996. The report stressed that targeting was poor. Countries with chronic food insecurity were not more targeted than countries with low levels of needs. Moreover, these countries frequently received limited amounts and on a one-time basis. The report suggested concentrating food aid on a limited number (around 15) of low-income countries, chronically in food deficit. Besides, it recommended that the EU be able to respond to specific circumstances like a temporary food aid gap.

The new Council Regulation (EC) No 1292/96 [1996] of 27 June 1996 adopted many recommendations presented in the report. Food aid principles were clearly expressed: aid should promote food security related to poverty, reduce food aid dependency, and food aid should be coordinated among EU member states. Food aid meant to alleviate chronic food insecurity should be provided only to countries involved in a coherent national food strategy oriented towards the poor. The EU should evaluate needs based on food deficit and food security through specific indicators.

The reform resulted in one fundamental change in aid allocation. The EU reduced the number of recipient countries (see Figure 1). The regulation should have affected quantities. However, the overall budget for food aid (including emergency food aid) decreased. Thus, just after the reform, the quantities received by remaining recipient countries did not increase despite the concentration on a more limited number of recipients (see Figure A.1 in Appendix A).

I will use this exogenous time variation - from other donors and recipients' perspective in the EU allocation as an instrument of the probability of receiving food aid from the EU. To identify a causal effect, I need to introduce cross-country variation. I use the fact that the reform did not affect all recipient countries uniformly. Countries that received food aid regularly before 1996 were more affected in absolute terms by the reform than countries that received it irregularly. To illustrate this point, I divide the 
countries into two groups, based on the frequency at which they received food aid from the EU before 1996.

Figure 2 shows that there is a noticeable drop in the probability of receiving food aid from the EU among regular recipients before 1996. Irregular recipients (below median) are also affected by the reform, but the impact is slighter. Regular recipients are on average poorer and more populous; they are also more likely to be affected by a natural disaster or a conflict than irregular. Table 1 provides descriptive statistics on the number of recipients by type of donor depending on recipient's type and before and after 1996 . It suggests a larger decrease in the number of regular recipients also for other donors.

When controlling for the levels of the interacted variables, this interaction term is excludable to country-specific variables because the timing of the reform is unrelated to recipients' needs. Given the timing of the reform and its heterogeneous impact, I instrument the EU allocation in Equation 1 as follows:

$$
F A_{E U r t}=\lambda R e \text { form }_{t} * P_{r}+X_{d r, t-1} \Gamma_{3}+X_{r, t-1} \Gamma_{4}+\phi_{d t}+\phi_{d r}+\epsilon_{d r t}
$$

with Reformt a dummy equal to one if the reform has been implemented (that is $t>1996)$ and $P_{r}$ the country's probability of receiving food aid from the EU before 1996. $P_{r}$ is equal to $\frac{1}{8} \sum_{t=1988}^{1995} F A_{E U r t}$. It is the share of years before the reform when a country $r$ received food aid from the EU. I do not compute the probability over the whole period but only before the reform to avoid capturing the impact of the reform.

The instrument uses variations induced by the reform across recipients as the reform did not affect them uniformly. Given figure 2, I expect $\lambda$ to be negative: the more often a country received food aid before the reform, the larger the drop in the probability of receiving food aid after the reform. The interaction term allows me to include year-donor fixed effects in the first-stage equation 2 , to control for changes over time 
that could be spuriously correlated with EU food aid allocation patterns. $\phi_{d t}$ also captures the direct and uniform impact of the reform on recipients. $\phi_{d r}$ controls for the direct time-invariant impact of $P_{r}$ on $F A_{E U r t}$.

The EU had to cut some countries once it had less food to distribute. This could be related to some characteristics, for which the evolution after 1996 is different. Hence, I include interactions between the controls and the timing of the reform, $X_{d r t} * R e f o r m_{t}$. As other donors have a decreasing trend in food aid budget, I include such interaction terms in the second-stage equation. Indeed, a common appraisal of how a recipient will be affected by shutting down food aid may drive part of the donors' behavior. Hence, I estimate the following two equations:

$$
\begin{aligned}
F A_{E U r t} & =\lambda \text { Reform } \text { for }_{t} * P_{r}+X_{d r, t-1} \Gamma_{3}+X_{r, t-1} \Gamma_{4} \\
& +X_{d r, t-1} * \text { Reform } \Gamma_{5}+X_{r, t-1} * \operatorname{Reform}_{t} \Gamma_{6}+\phi_{d t}+\phi_{d r}+\epsilon_{d r t}
\end{aligned}
$$

and

$$
\begin{aligned}
F A_{d r t} & =\beta F A_{E U r t}+X_{d r, t-1} \Gamma_{1}+X_{r, t-1} \Gamma_{2}+X_{d r, t-1} * \text { Reform }_{t} \Gamma_{6}+X_{r, t-1} * \text { Reform } \Gamma_{7} \Gamma_{7} \\
& +\phi_{d t}+\phi_{d r}+\epsilon_{d r t}
\end{aligned}
$$

A specific concern arises for EU member states. The reform may have induced bilateral reforms in line with the EU's reform. I have not obtained any evidence of reforms of food aid policy at the national level in the years around the EU reform. I have found concerns France which assessed its programs [Thirion, 1996]. ${ }^{4}$ I am thus aware that even in the absence of a formal reform, this assessment may have shaped bilateral food aid policies.

EU members may have influenced the allocation of EU food aid before and after the reform, especially the largest member countries. The way the EU Commission decides on the allocation and the exchanges with EU representatives seem to prevent manipulation. 
Depending on recipients' requests, the Commission first establishes proposals of food aid allocation. Next, the Food Aid Committee, which includes civil servants from the Commission and EU representatives, agrees or disagrees with the proposals made by the Commission. In practice, the Committee has never rejected a proposal [Clay et al., 1996]. The role of the Food Aid Committee has decreased over the years and is now negligible. The Commission has been much more independent. ${ }^{5}$ It has been shown that holding the presidency of the Council of the European Union may affect foreign aid allocation [Aronow et al., 2017]. [Gehring and Schneider, 2018] show that the nationality of EU commissioners also matters for the allocation of the European budget. During the reform period (1995-1997), only small donor countries held the presidency as for the

Commissioner for Development and Humanitarian Aid and Civil Protection nationality.

Nevertheless, given these specific concerns regarding EU member states, I first focus the analysis on non-EU regular donors, which include the two largest donors, the US, and Japan. I include them afterward and see how the results are affected.

\section{Results}

\subsection{Baseline}

The OLS estimates of Equation 4 for donor allocation are reported in the first lines of Table 2. Column (1) controls only for fixed effects. Column (2) includes a range of time-variant variables, $X_{r t-1}$, as well as those controls interacted with the timing of the EU reform. In column (3), additional controls are related to the quality of the recipient's government. Column (4) includes time-variant donor-recipient variables, $X_{d r t-1}$. The coefficient of interest is positive and significant at the one percent level. The relationship tends to weaken with the inclusion of additional controls.

The first stage of the 2SLS estimation shows a strong negative correlation between the 
instrument and the EU choice of giving food aid (2). According to estimates in column (4) for a country that received food from the EU every year before 1996 (that is $\mathrm{P}_{r}=1$ ), the reform induced a decrease in its probability of receiving EU food aid by 67 percentage points.

Without any controls, the 2SLS estimate is not significant and smaller than the OLS estimates. In column (2) and (3) the estimate is smaller and significant at the one percent level. If the EU allocates aid to a recipient country, it increases by 5.7 percentage points the probability of receiving food aid from another donor (column (4)). The effect could appear to be moderate, but they are in line with results on ODA [Davies and Klasen, 2019]. The comparison between the OLS and 2SLS estimates suggests an upward bias in line with a common reaction of donors to unobserved shocks as suggested by Kuhlgatz et al. [2010] or a herding behavior.

The sample mean of the probability of receiving food aid from a non-EU member donor is 30.5 percent before the reform, and the average probability of receiving food aid from the $\mathrm{EU}$ is 62.7 percent. Therefore, for a recipient country at the mean level of EU probability, the estimate implies a decrease by 10 percentage points of the probability of receiving food aid from the EU causes a 0.57 percentage point decrease in the average probability of receiving food aid from other donors, that is 1.8 percent of the sample mean. As the EU reform is equivalent to a 32.2 percentage point decrease in the probability of receiving EU food aid, it means that on average one recipient out of five experienced a decrease by one in the number of non-EU donors. For a recipient who always received food aid from the EU before the reform and does not receive it anymore, it induces a decrease in the number of other donors by 0.5 .

Next, I extend the analysis to EU member states (first part, column 2 of table 3). EU members tend to react more positively, in line with the information signal from the EU to European countries. 
Finally, to net out all the strategic interactions between donors, I consider the extreme case for which I aggregate all non-EU donors together as if there were only two donors, the EU and the rest of the world (RoW). In that case, the dependent variable is equal to one if at least one non-EU donor allocates food aid to the recipient country and controls are the same as in column (3). It provides an idea of how all non-EU food aid responds to EU food aid. The estimate is nine times larger than before.

I provide results on the reaction on quantities (in equivalent calories) on table 4.

Column (1) estimates the reaction of donors on quantity (including 0) to the extensive margin of the EU. Column (2) looks at the reaction on the intensive margin of donors to the extensive margin of the EU. Column (3) estimates the reaction of donors on quantity to the quantity (including 0) allocated by the EU. Column (4) looks at the reaction on the extensive margin of donors to the quantity (including 0) allocated by the EU. Coefficients of columns (2) and (4) should be carefully interpreted conditional on giving food aid.

Herding behavior is relevant in quantities. Not only donors react at the extensive margin, but they also react at the intensive margin. The leverage effect of the EU is key to provide enough food aid to recipients.

\subsection{Bilateral Reactions}

I estimate Equations 3 and 4 for each donor $d$ separately allowing for a differentiated response, $\beta_{d}$ (table 5$)$.

Bilateral reactions are heterogeneous, but the estimates are between -1 and 1 . Alone, a donor cannot entirely compensate the EU withdraw. The lack of significant reaction

from the US supports the theoretical framework developed by Annen and Moers [2016]. It is also the case for small non-European donors. Canada, a donor with a similar 
budget, steps in the EU as expected in previous section. The positive reaction of European donors, especially small Nordic donors, supports the third hypothesis on information. Reaction is higher for France and Germany than Scandinavian countries, in line with our fourth hypothesis.

Only results for Japan are not in line with the hypothesis. The absence of interaction suggests that private interests may be compensated by the public good effect on allocation. This result is coherent with previous findings from Berthélemy [2006] labeling Japan as moderate egoistic. ${ }^{6}$

The WFP substitutes to the EU and starts allocating food aid to former EU recipient countries. The WFP tries first to obtain food aid from other donors through special appeals or core contributions, before spending on its own. Thus, the WFP appears as a donor of last resort.

The WFP is also the implementing agency of numerous donors but herding behavior cannot fully be explained by it. Donors contribute to multilateral funds administered by the WFP as the Immediate Response Account. Such contribution appears as bilateral in INTERFAIS. The importance of multilateral funds is increasing but was low until 2004. The EU does not contribute to such funds. Hence food aid from other donors cannot coordinate with the EU through this mechanism.

The findings on European donors highlight the question of the subsidiarity and of the efficiency of having two levels of food aid allocation, at the country and at the EU level, if both target the same recipients. A solution that could preserve bilateral allocation by EU member states while reducing costs would be to increase the number of food aid projects co-financed by the EU and an EU member state. It is already partly the case with policies such as joint programming, but it is unsystematic and the implementation of this policy still remains imperfect. 


\subsection{Potential Concerns}

Causal inference using the interacted variable, $\operatorname{Reform}{ }_{t} * P_{r}$, relies on the assumption that, conditional on the controls, the interaction between the reform dummy and the recipient's probability of receiving EU food aid before the reform only affects food aid allocation from other donors through the EU food aid allocation pattern. Numerous concerns could arise when making such an assumption.

Given the size of EU food aid and the number of recipients involved, the reform could not be completely implemented in one year. Moreover, project and program food aid are often scaled over two or three years; the EU may have decided not to renew them rather than stop an ongoing project. The EU decided which countries were to be affected by the reform first and stopped allocating food aid to small countries first. ${ }^{7}$ The amounts of food aid allocated to small countries were smaller, administrative constraints and bureaucratic ties may also have been weaker, and these countries may have offered fewer opportunities in terms of economic and geopolitical development for the EU. As a result, small countries stopped receiving food aid from the EU after 1996 and only received emergency food aid from time to time afterwards. For larger countries, the implementation of the reform took longer.

For internal validity, I should focus on small recipient countries first. Indeed, other donors may have learned from the first phase of the reform and adapted their reaction. Donors may react differently to small and large recipients. Table 3 shows the reaction of other donors to the EU for small countries. The reactions are stronger.

The reform was a consequence of the reform of the EU agricultural policy. The timing of the reform could have affected other donors' allocation through EU agricultural exports. I find that EU agricultural exports to regular recipient countries were not significantly lower than EU agricultural exports to irregular recipients after the reform. EU 
agricultural exports were not substituted for food aid. If anything, this should have increased the probability of receiving food aid from other donors, while the opposite occurs. To be cautious, the analysis addresses this possibility by controlling EU agricultural exports to the recipient country.

In 1996, the US ratified a new Farm Bill. As a consequence, theoretically, food aid should have had to make a final transition from a government-surplus-based to a budget-based regime. The effect could be due to a reaction to the US changes. However, Barrett and Maxwell [2005] note that 'this potential for reform has gone untapped. Indeed, and perhaps ironically, food aid now tracks domestic food stocks more closely than ever'. Finally, the amount of food aid allocated by the US increased substantially from 1995 to 1996. However, I find the US does not react significantly to the EU allocation, but the estimate is positive, meaning that the US did not increase its probability of allocating food aid to those recipient countries, despite the increase in the budget.

The first stage is similar to a difference-in-difference. One of the key assumptions is the parallel trend before the reform. I test whether the changes in the EU allocation before the reform were similar for regular and non-regular countries. The parallel trend assumption holds (B.1 in Appendix B).

Non-European donors may not distinguish between food aid from the EU and food aid from European donors. The estimate is twice higher when I include bilateral European aid. It suggests that non-European donors reacted to both multilateral and bilateral EU food aid allocation. However, K.-P. F-stat is low because the reform only affected multilateral EU aid (see row (5) in Table 6). 


\subsection{Robustness}

I test the sensitivity of the baseline estimates to the sample definition (Table 6). First, I replace the set of donors. In row (2), I include all donors. In row (3) and (4), I restrict the sample to donors which gave food aid respectively at least 10 or 20 years. The estimates remain significantly positive. However, the order of magnitude is lower.

Second, I vary the period of analysis to exclude events that could have affected (food) aid allocation. One could think of the end of the Cold War, the 9/11/2001 attacks, or the Paris Declaration on Aid Effectiveness in 2005 (row (6) to (8)). In row (9), I narrow the analysis to one year before and after the reform. The estimate is not significant at the 10 percent level. The first-stage estimate is no longer significant even if it remains negative. Third, in row (10) I exclude split countries and small countries. The estimate is significantly positive and higher than before.

Next, I revise the first-stage specification. I replace $P_{r}$ by the previous year's allocation, $F A_{E U t-1}$, (row (11)) or recent past allocation, by computing the probability of receiving food aid from the EU between 1993-1995 (row (12)). In that case, donors would not be reacting to the EU's long-term allocation but its short-term allocation. The K.-P. F-Stat decreases as expected. The estimate is not significant suggesting that donors focus on trend allocation rather than on the EU's year-to-year allocation. It may also suggest that donors value long term information from the EU rather than transitory additional information, contrary to the results for development aid provided by Davies and Klasen [2019]. The results based on the last three years are similar to those based on the whole period before the reform.

I also compute the probability of receiving project or program food aid excluding emergency food aid in row (13), as the former were the targets of the reform. The estimate is similar. 
In Table 7, I run different placebo tests. First, I estimate alternative first-stage equations in which the reform is assumed to have occurred in 1992 - which corresponds to the year of the CAP reform - or 2003. The estimate is not significant neither the second-stage.

The reform should only have affected the allocation of food aid from the EU. However, it could be the case that the EU substituted other types of aid to food aid. The other donors may have reacted to such aid. I find no impact of the reform on the amount of development and humanitarian aid allocated to recipient countries by the EU (row (3) of table 7 ).

\section{Conclusion}

The EU reform in 1996, which resulted in many countries no longer receiving aid from the EU, affected food aid allocation by other donors. On average, donors imitate the EU allocation: they stopped giving to recipients following the EU's withdrawal. I find large heterogeneity in donors' reactions: Nordic and European countries as well as Canada imitate the EU. On the contrary, the WFP mitigated the decrease. Other donors do not react to the EU allocation, especially the US. For European donors, the EU allocation provides information on recipients and may explain why they follow the EU. For Canada, the competition effect seems more relevant. For the US, domestic concerns or competition effects can explain the reactions. Results are robust when looking at quantities.

These results have implications for coordination and fragmentation, as well as from a European perspective. First, herding behavior reinforces the problem of darling and orphan countries as all donors will allocate aid to the same recipients. The WFP is still a too small donor to compensate the effect of herding behavior from other donors. As donors tend to step in with the EU allocation, coordination through joint response is 
more likely to be efficiently implemented than division of labor. Nevertheless, joint responses highlights the question of duplication of fixed costs and project fragmentation if coordination is not well implemented.

At the European level, it raises the problem of subsidiarity between the EU and its member states and the efficiency of having two levels of food aid allocation. It should be investigated carefully in a context of growing joint response initiatives, as the Joint Programming Initiative. Some authors already show that, even within the EU for which I find herding behavior, joint response is difficult to implement because of private interests from EU member states [Carbone, 2017]. Donors prefer implementing their own projects rather than implementing common projects.

\section{Notes}

1 "Food is a weapon much more than other type of aid because you can starve people" (Butz (US Foreign Secretary), 1967).

${ }^{2}$ Results are robust to the use of lagged EU food aid.

${ }^{3}$ Data are provided by DAC-OECD. I exclude sector code 520.

${ }^{4}$ I have not obtained a copy of this document.

${ }^{5}$ Since the ratification of the Lisbon Treaty (2009), the Commission no longer needs approval from EU member states on the allocation of food and humanitarian aid.

${ }^{6}$ For the US and Japan, other explanation may explain an absence of significant reaction. Indeed their food aid policy is mostly driven by agricultural surplus and domestic political concerns [Barrett and Maxwell, 2005].

${ }^{7}$ The World Bank definition is countries that have a population of 1.5 million or less, or are members of the Small States Forum. 


\section{Conflict of interest statement}

On behalf of all authors, the corresponding author states that there is no conflict of interest.

\section{References}

M. Aaltola. Emergency Food Aid as a Means of Political Persuasion in the North Korean Famine. Third World Quarterly, 20(2):371-386, 1999.

K. Annen and L. Moers. Donor competition for aid impact, and aid fragmentation. The World Bank Economic Review, 2016.

P. M. Aronow, A. Carnegie, and N. Marinov. Foreign Aid, Human Rights and Democracy Promotion: Evidence from a Natural Experiment. American Journal of Political Science, 61(3):671-683, 2017.

C. Barrett and D. Maxwell. Food Aid After Fifty Years: Recasting Its Role. Priorities for development economics. Routledge, 2005.

C. B. Barrett and K. C. Heisey. How Effectively Does Multilateral Food Aid Respond to Fluctuating Needs? Food Policy, 27(5-6):477-491, 2002.

M. F. Bellemare, T. Masaki, and T. B. Pepinsky. Lagged explanatory variables and the estimation of causal effect. The Journal of Politics, 79(3):949-963, 2017.

J.-C. Berthélemy. Bilateral Donor's Interest vs. Recipients' Development Motives in Aid Allocation: Do All Donors Behave the Same? Review of Development Economics, 10 (2):179-194, 2006.

T. Besley and R. Burgess. The Political Economy Of Government Responsiveness: Theory and Evidence From India. The Quarterly Journal of Economics, 117(4): $1415-1451,2002$. 
F. Bourguignon and J.-P. Platteau. The Hard Challenge of Aid Coordination. World Development, 69:86 - 97, 2015. Aid Policy and the Macroeconomic Management of Aid.

M. Carbone. Make europe happen on the ground? enabling and constraining factors for european union aid coordination in africa. Development Policy Review, 35(4):531-548, 2017. doi: 10.1111/dpr.12194.

E. J. Clay, S. Dhiri, and C. Benson. Joint Evaluation of European Union Programme Food Aid. Ministry of Foreign Affairs, Danida, 1996.

Council Regulation (EC) No 1292/96. Council Regulation (EC) No 1292/96 of 27 June 1996 on food-aid policy and food-aid management and special operations in support of food security. Official Journal of the European Communities, June 1996.

R. B. Davies and S. Klasen. Darlings and orphans: Interactions across donors in international aid. The Scandinavian Journal of Economics, 121(1):243-277, 2019.

N. Ferrière and A. Suwa-Eisenmann. Does food aid disrupt local food market? evidence from rural ethiopia. World Development, 76:114-131, 2015. ISSN 0305-750X.

E. Frot and J. Santiso. Herding in Aid Allocation. Kyklos, 64(1):54-74, 2011.

A. Fuchs, P. Nunnenkamp, and H. Öhler. Why Donors of Foreign Aid Do Not Coordinate: The Role of Competition for Export Markets and Political Support. The World Economy, 38(2):255-285, 022015.

S. Galiani, S. Knack, L. C. Xu, and B. Zou. The effect of aid on growth: evidence from a Quasi-experiment. Journal of Economic Growth, 22(1):1-33, March 2017.

S. Gates and A. Hoeffler. Global aid allocation: Are nordic donors different? Technical report, CSAE WPS, 2004. 
K. Gehring and S. A. Schneider. Towards the Greater Good? EU Commissioners' Nationality and Budget Allocation in the European Union. American Economic Journal: Economic Policy, 10(1):214-39, February 2018.

T. Kim. Strategizing aid: US-China food aid relations to North Korea in the 1990s. International Relations of the Asia-Pacific, 2011.

C. Kuhlgatz, A. Abdulai, and C. B. Barrett. Food Aid Allocation Policies: Coordination and Responsiveness to Recipient Country Needs. Agricultural Economics, 41(3-4): 319-327, 052010.

R. Mascarenhas and T. Sandler. Do donors cooperatively fund foreign aid? The Review of International Organizations, 1(4):337-357, Dec 2006.

E. Neumayer. Is the Allocation of Food Aid Free from Donor Interest Bias? Journal of Development Studies, 41(3):394-411, 2005.

N. Nunn and N. Qian. US Food Aid and Civil Conflict. The American Economic Review, 104(6):1630-1666, 2014.

A. R. Quisumbing. Food aid and child nutrition in rural Ethiopia. World Development, 31(7):1309-1324, 2003.

A. Strezhnev and E. Voeten. United Nations General Assembly Voting Data. Data, 2012.

M.-C. Thirion. Aide alimentaire française, éléments de diagnostic. SEAH, October 1996.

D. Tingley. Donors and Domestic Politics: Political Influences on Foreign Aid Effort. The Quarterly Review of Economics and Finance, 50(1):40 - 49, 2010. Special Section: Foreign Aid.

L. Vesterlund. The Informational Value of Sequential Fundraising. Journal of Public Economics, 87(3):627-657, 2003. 
E. Werker, F. Z. Ahmed, and C. Cohen. How is Foreign Aid Spent? Evidence from a Natural Experiment. American Economic Journal: Macroeconomics, pages 225-244, 2009.

WFP. Food Aid Information System, World Food Programme, available at: http://www.wfp.org/fais/, 2011.

WFP. How climate drives hunger: Food security climate analyses, methodologies and lessons 2010-2016. Technical report, WFP, Climate Resilience for Food Security, 2017.

N. Zahariadis, R. Travis, and J. B. Ward. US Food Aid to Sub-Saharan Africa: Politics or Philanthropy? Social Science Quarterly, 81(2):663-676, 2000. 


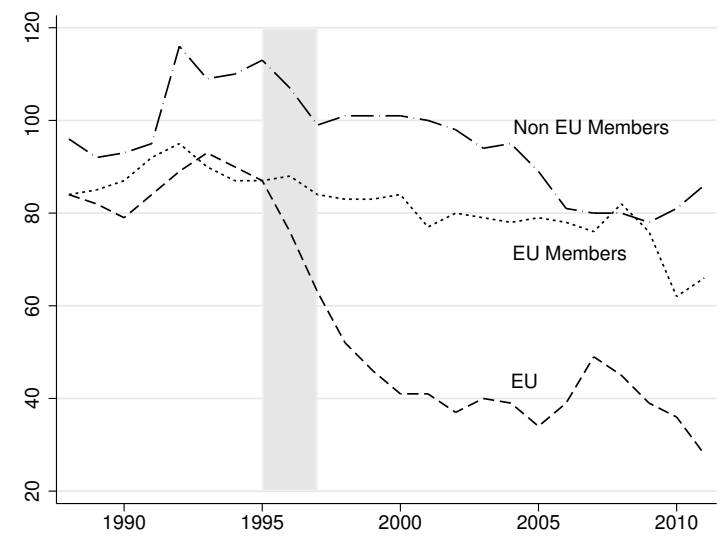

Figure 1: Number of recipient countries by group of donors

Notes: Author calculations. For this figure a country is a recipient if at least one regular donor within the group allocates food aid to this country. 


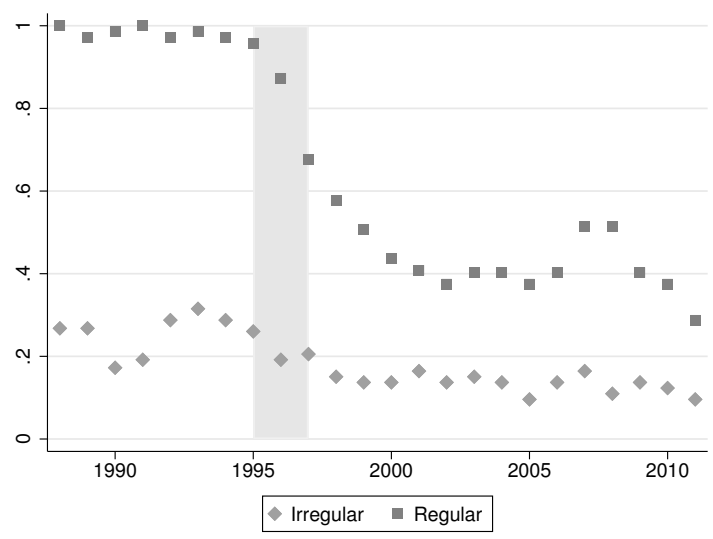

Figure 2: Probability of receiving food aid from the EU

Notes: Author calculations. Regular recipients are countries whose probability of receiving food aid from the EU before 1996 is above 0.78 - the sample median value. Irregular recipients are other countries. 


\begin{tabular}{ccccc}
\hline & \multicolumn{2}{c}{ Irregular recipients } & \multicolumn{2}{c}{ Regular recipients } \\
& Before 1996 & After 1996 & Before 1996 & After 1996 \\
\hline EU & 17.25 & 10.38 & 68.75 & 33.69 \\
EU members & 22.63 & 20.63 & 65.75 & 58.50 \\
Non EU members & 35.13 & 29.50 & 67.88 & 62.44 \\
\hline
\end{tabular}

Table 1: Average number of recipients

Notes: Author's calculation. Regular recipients are countries whose probability of receiving food aid from the EU before 1996 is above 0.78 (median value). Irregular recipients are other countries. For EU members, a country is a recipient if the country receives food aid from at least one EU member. A country is a recipient from non EU countries if the country receives food aid from at least one non EU country donor. 


\begin{tabular}{|c|c|c|c|c|}
\hline \multirow[t]{2}{*}{ Dependent variable } & \multicolumn{4}{|c|}{ Has received food aid from $d$} \\
\hline & (1) & $(2)$ & (3) & (4) \\
\hline \multicolumn{5}{|l|}{ OLS } \\
\hline Has received EU food aid & $\begin{array}{c}0.115^{* * *} \\
(0.018)\end{array}$ & $\begin{array}{c}0.083^{* * *} \\
(0.014)\end{array}$ & $\begin{array}{c}0.086^{* * *} \\
(0.014)\end{array}$ & $\begin{array}{c}0.078^{* * *} \\
(0.014)\end{array}$ \\
\hline $\mathrm{R}^{2}$ & 0.480 & 0.498 & 0.493 & 0.491 \\
\hline \multicolumn{5}{|l|}{ Reduced Form } \\
\hline $\operatorname{Reform}_{t} * \mathrm{P}_{r}$ & $\begin{array}{l}-0.007 \\
(0.030)\end{array}$ & $\begin{array}{l}-0.042 \\
(0.030)\end{array}$ & $\begin{array}{l}-0.045 \\
(0.032)\end{array}$ & $\begin{array}{l}-0.037 \\
(0.033)\end{array}$ \\
\hline $\mathrm{R}^{2}$ & 0.472 & 0.494 & 0.489 & 0.488 \\
\hline \multicolumn{5}{|l|}{$2 \mathrm{SLS}$} \\
\hline Has received EU food aid & $\begin{array}{c}0.012 \\
(0.022)\end{array}$ & $\begin{array}{l}0.065^{* *} \\
(0.025)\end{array}$ & $\begin{array}{l}0.068^{* *} \\
(0.027)\end{array}$ & $\begin{array}{l}0.056^{* *} \\
(0.027)\end{array}$ \\
\hline $\mathrm{R}^{2}$ & 0.472 & 0.494 & 0.489 & 0.488 \\
\hline Dependent variable & \multicolumn{4}{|c|}{ Has received EU food aid } \\
\hline \multicolumn{5}{|l|}{ First Stage } \\
\hline $\operatorname{Reform}_{t} * \mathrm{P}_{r}$ & $\begin{array}{c}-0.538^{* * *} \\
(0.057)\end{array}$ & $\begin{array}{c}-0.649^{* * *} \\
(0.074)\end{array}$ & $\begin{array}{c}-0.655^{* * *} \\
(0.074)\end{array}$ & $\begin{array}{c}-0.667^{* * *} \\
(0.071)\end{array}$ \\
\hline $\mathrm{R}^{2}$ & 0.541 & 0.577 & 0.565 & 0.588 \\
\hline K-P. F-Stat & 89.722 & 76.920 & 79.371 & 83.676 \\
\hline Observations & 30600 & 26063 & 23858 & 21770 \\
\hline Donor-Recipient pairs & 1305 & 1224 & 1107 & 1097 \\
\hline Recipients & 145 & 136 & 123 & 122 \\
\hline Donor-Recipient FE & Yes & Yes & Yes & Yes \\
\hline Donor-Year FE & Yes & Yes & Yes & Yes \\
\hline Any conflict ${ }_{r-1}$ & No & Yes & Yes & Yes \\
\hline Any neighbor conflict $_{r t-1}$ & No & Yes & Yes & Yes \\
\hline Any disaster $r t$ & No & Yes & Yes & Yes \\
\hline Any disaster $r t-1$ & No & Yes & Yes & Yes \\
\hline $\log (\text { Cereal production per capita })_{r t-1}$ & No & Yes & Yes & Yes \\
\hline $\log (\text { Population (millions) })_{r t-1}$ & No & Yes & Yes & Yes \\
\hline $\log (\text { GDP per capita })_{r t-1}$ & No & Yes & Yes & Yes \\
\hline Share of refugees in country $y_{r t-1}$ & No & Yes & Yes & Yes \\
\hline $\log (\text { EU agricultural export })_{r t-1}$ & No & Yes & Yes & Yes \\
\hline Democratic Index $_{r t-1}$ & No & No & Yes & Yes \\
\hline Political rights and civil liberties $_{r t-1}$ & No & No & Yes & Yes \\
\hline UN Vote Index ${ }_{d r t-1}$ & No & No & No & Yes \\
\hline Any other aid from donor $d_{d r t-1}$ & No & No & No & Yes \\
\hline $\mathrm{X}_{r t-1} * \operatorname{Reform}_{t}$ & No & No & Yes & Yes \\
\hline $\mathrm{X}_{d r t-1} *$ Reform $_{t}$ & No & No & No & Yes \\
\hline
\end{tabular}

Table 2: Donors' reaction to the allocation of EU food aid on the decision stage - Non-EU members - Food aid

Notes: An observation is a donor-recipient pair and a year. The sample is composed by regular donors outside the EU from 1988 to 2011. Standard errors bootstrapped and clustered at the recipient and year level in parenthesis. $P_{r}$ is the average probability of receiving food aid from the EU before 1996.*** $p<0.01, * * p<0.05, * p<0.1$ 


\begin{tabular}{|c|c|c|c|}
\hline \multirow[b]{2}{*}{ Donors } & \multicolumn{3}{|c|}{ All countries } \\
\hline & Non EU & All & RoW \\
\hline \multicolumn{4}{|l|}{ 2SLS } \\
\hline Has received EU food aid & $\begin{array}{l}0.057^{* *} \\
(0.027)\end{array}$ & $\begin{array}{r}0.085^{* * *} \\
(0.023)\end{array}$ & $\begin{array}{l}0.509^{* *} \\
(0.244)\end{array}$ \\
\hline $\mathrm{R}^{2}$ & 0.488 & 0.438 & 0.700 \\
\hline \multicolumn{4}{|l|}{ OLS } \\
\hline Has received EU food aid & $\begin{array}{r}0.078^{* * *} \\
(0.014)\end{array}$ & $\begin{array}{r}0.078^{* * *} \\
(0.013)\end{array}$ & $\begin{array}{r}0.763^{* * *} \\
(0.130)\end{array}$ \\
\hline $\mathrm{R}^{2}$ & 0.491 & 0.442 & 0.713 \\
\hline \multicolumn{4}{|l|}{ First Stage } \\
\hline $\operatorname{Reform}_{t}{ }^{*} \mathrm{P}_{r}$ & $\begin{array}{r}-0.665^{* * *} \\
(0.072)\end{array}$ & $\begin{array}{r}-0.665^{* * *} \\
(0.072)\end{array}$ & $\begin{array}{r}-0.659^{* * *} \\
(0.074)\end{array}$ \\
\hline $\mathrm{R}^{2}$ & 0.491 & 0.442 & 0.712 \\
\hline K-P. F-Stat & 83.676 & 83.356 & 78.149 \\
\hline Observations & 21770 & 50233 & 2651 \\
\hline Donor-Recipient pairs & 1097 & 2439 & 123 \\
\hline \multirow[t]{2}{*}{ Recipients } & 122 & 122 & 123 \\
\hline & \multicolumn{3}{|c|}{ Only small countries } \\
\hline Donors & Non EU & All & RoW \\
\hline \multicolumn{4}{|l|}{$2 \mathrm{SLS}$} \\
\hline Has received EU food aid & $\begin{array}{r}0.228^{* * *} \\
(0.050)\end{array}$ & $\begin{array}{r}0.217^{* * *} \\
(0.042)\end{array}$ & $\begin{array}{r}2.056^{* * *} \\
(0.453)\end{array}$ \\
\hline $\mathrm{R}^{2}$ & 0.402 & 0.387 & 0.637 \\
\hline \multicolumn{4}{|l|}{ OLS } \\
\hline Has received EU food aid & $\begin{array}{l}0.090^{* *} \\
(0.031)\end{array}$ & $\begin{array}{l}0.076^{* *} \\
(0.032)\end{array}$ & $\begin{array}{l}0.812^{* *} \\
(0.291)\end{array}$ \\
\hline $\mathrm{R}^{2}$ & 0.402 & 0.386 & 0.635 \\
\hline \multicolumn{4}{|l|}{ First Stage } \\
\hline $\operatorname{Reform}_{t} * \mathrm{P}_{r}$ & $\begin{array}{r}-0.929^{* * *} \\
(0.092)\end{array}$ & $\begin{array}{r}-0.929^{* * *} \\
(0.092)\end{array}$ & $\begin{array}{r}-0.929^{* * *} \\
(0.092)\end{array}$ \\
\hline $\mathrm{R}^{2}$ & 0.392 & 0.375 & 0.593 \\
\hline K-P. F-Stat & 161.989 & 162.532 & 154.079 \\
\hline Observations & 3636 & 8080 & 404 \\
\hline Donor-Recipient pairs & 162 & 360 & 18 \\
\hline Recipients & 18 & 18 & 18 \\
\hline Controls from table 3 & Column (4) & Column (4) & Column (3) \\
\hline
\end{tabular}

Table 3: Strategic interactions depending on the sample of food aid donors and the sample of recipients

Notes: One observation is a pair donor-recipient and a year. The sample includes 122 recipient countries (18 small countries) and 21 regular donors (except the EU) from 1988 to 2011 . Standard errors in parenthesis, bootstrapped and clustered at the recipient and year level. RoW considers all non-EU donors as one donor. $* * * p<0.01, * * p<0.05, * p<0.1$ 


\begin{tabular}{|c|c|c|c|c|}
\hline OLS & Food aid & Quantity $>0$ & Food aid & Quantity $>0$ \\
\hline Has received EU food aid & $\begin{array}{c}1.842^{* * *} \\
(0.330)\end{array}$ & $\begin{array}{c}0.223^{* * *} \\
(0.065)\end{array}$ & & \\
\hline Quantity of EU food aid & & & $\begin{array}{c}0.079^{* * *} \\
(0.016)\end{array}$ & $\begin{array}{l}0.010^{* *} \\
(0.004)\end{array}$ \\
\hline $\begin{array}{l}R^{2} \\
\text { 2SLS }\end{array}$ & 0.529 & 0.674 & 0.529 & 0.674 \\
\hline Has received EU food aid & $\begin{array}{l}1.588^{* *} \\
(0.627)\end{array}$ & $\begin{array}{l}1.119^{* *} \\
(0.502)\end{array}$ & & \\
\hline Quantity of EU food aid & & & $\begin{array}{l}0.056^{* *} \\
(0.028)\end{array}$ & $\begin{array}{l}0.044^{* *} \\
(0.020)\end{array}$ \\
\hline $\mathrm{R}^{2}$ & \multicolumn{4}{|c|}{ EU food aid } \\
\hline First stage & & & & \\
\hline Reform $_{t} * \mathrm{P}_{r}$ & $\begin{array}{c}-0.665^{* * *} \\
(0.073)\end{array}$ & $\begin{array}{c}-0.513^{* * *} \\
(0.116)\end{array}$ & $\begin{array}{c}-0.631^{* * *} \\
(0.079)\end{array}$ & $\begin{array}{c}-13.078^{* * *} \\
(2.905)\end{array}$ \\
\hline $\mathrm{R}^{2}$ & 0.567 & 0.394 & 0.587 & 0.439 \\
\hline K-P. F-Stat & 83.676 & 19.455 & 64.394 & 20.279 \\
\hline Observations & 21770 & 5767 & 21770 & 5767 \\
\hline Donor-Recipient pairs & 1097 & 634 & 1097 & 634 \\
\hline Donor-Recipient FE & Yes & Yes & Yes & Yes \\
\hline Controls from table 3 & Column (4) & Column (4) & Column (4) & Column (4) \\
\hline
\end{tabular}

Table 4: Reactions on quantities

Notes: One observation is a pair donor-recipient and a year. standard errors in parenthesis, bootstrapped and clustered at the recipient and year level. $* * * p<0.01, * * p<0.05, * p<0.1$ 


\begin{tabular}{|c|c|c|c|c|}
\hline & \multicolumn{4}{|c|}{ Non EU members } \\
\hline & 2SLS & First stage & OLS & K-P. F-Stat \\
\hline Australia & $\begin{array}{l}0.101 \\
(0.068)\end{array}$ & $\begin{array}{l}-0.655^{* * *} \\
(0.074)\end{array}$ & $\begin{array}{l}0.103^{* * *} \\
(0.022)\end{array}$ & 78.721 \\
\hline Canada & $\begin{array}{l}0.525^{* * *} \\
(0.074)\end{array}$ & $\begin{array}{l}-0.655^{* * *} \\
(0.074)\end{array}$ & $\begin{array}{l}0.218^{* * *} \\
(0.030)\end{array}$ & 78.735 \\
\hline Japan & $\begin{array}{l}0.024 \\
(0.066)\end{array}$ & $\begin{array}{l}-0.656^{* * *} \\
(0.074)\end{array}$ & $\begin{array}{l}0.081^{* *} \\
(0.032)\end{array}$ & 78.718 \\
\hline Norway & $\begin{array}{l}0.103 \\
(0.067)\end{array}$ & $\begin{array}{l}-0.655^{* * *} \\
(0.074)\end{array}$ & $\begin{array}{l}0.073^{* *} \\
(0.031)\end{array}$ & 78.747 \\
\hline Saudi Arabia & $\begin{array}{l}0.024 \\
(0.038)\end{array}$ & $\begin{array}{l}-0.656^{* * *} \\
(0.074)\end{array}$ & $\begin{array}{l}0.022 \\
(0.022)\end{array}$ & 78.664 \\
\hline Switzerland & $\begin{array}{l}0.125 \\
(0.076)\end{array}$ & $\begin{array}{l}-0.655^{* * *} \\
(0.074)\end{array}$ & $\begin{array}{l}0.093^{* * *} \\
(0.026)\end{array}$ & 78.691 \\
\hline UN Institutions & $\begin{array}{l}-0.054 \\
(0.045)\end{array}$ & $\begin{array}{l}-0.655^{* * *} \\
(0.074)\end{array}$ & $\begin{array}{l}0.066^{*} \\
(0.032)\end{array}$ & 78.866 \\
\hline United States & $\begin{array}{l}0.024 \\
(0.075)\end{array}$ & $\begin{array}{l}-0.655^{\text {*** }} \\
(0.074)\end{array}$ & $\begin{array}{l}0.095^{* * *} \\
(0.032)\end{array}$ & 78.779 \\
\hline \multirow[t]{2}{*}{ WFP } & $\begin{array}{l}-0.256^{* * *} \\
(0.055)\end{array}$ & $\begin{array}{l}-0.656^{* * *} \\
(0.074)\end{array}$ & $\begin{array}{l}0.023 \\
(0.029)\end{array}$ & 78.664 \\
\hline & \multicolumn{4}{|c|}{ EU members } \\
\hline Austria & $\begin{array}{l}0.155^{* * *} \\
(0.048)\end{array}$ & $\begin{array}{l}-0.655^{* * *} \\
(0.074)\end{array}$ & $\begin{array}{l}0.050^{* *} \\
(0.019)\end{array}$ & 78.721 \\
\hline Belgium & $\begin{array}{l}0.054 \\
(0.046)\end{array}$ & $\begin{array}{l}-0.655^{* * *} \\
(0.074)\end{array}$ & $\begin{array}{l}0.047^{* *} \\
(0.017)\end{array}$ & 78.721 \\
\hline Denmark & $\begin{array}{l}0.142^{* *} \\
(0.072)\end{array}$ & $\begin{array}{l}-0.655^{* * *} \\
(0.074)\end{array}$ & $\begin{array}{l}0.066^{*} \\
(0.032)\end{array}$ & 78.806 \\
\hline Finland & $\begin{array}{l}0.120^{*} \\
(0.071)\end{array}$ & $\begin{array}{l}-0.655^{* * *} \\
(0.074)\end{array}$ & $\begin{array}{l}0.049 \\
(0.032)\end{array}$ & 78.747 \\
\hline France & $\begin{array}{l}0.178^{* * *} \\
(0.066)\end{array}$ & $\begin{array}{l}-0.655^{* * *} \\
(0.074)\end{array}$ & $\begin{array}{l}0.090^{* * *} \\
(0.021)\end{array}$ & 78.718 \\
\hline Germany & $\begin{array}{l}0.190^{* *} \\
(0.083)\end{array}$ & $\begin{array}{l}-0.655^{* * *} \\
(0.074)\end{array}$ & $\begin{array}{l}0.099^{* * *} \\
(0.032)\end{array}$ & 78.940 \\
\hline Italy & $\begin{array}{l}0.101 \\
(0.078)\end{array}$ & $\begin{array}{l}-0.655^{* * *} \\
(0.074)\end{array}$ & $\begin{array}{l}0.119^{* * *} \\
(0.026)\end{array}$ & 78.779 \\
\hline Luxembourg & $\begin{array}{l}0.054 \\
(0.046)\end{array}$ & $\begin{array}{l}-0.655^{* * *} \\
(0.074)\end{array}$ & $\begin{array}{l}0.047^{* *} \\
(0.017)\end{array}$ & 78.721 \\
\hline The Netherlands & $\begin{array}{l}0.155^{* *} \\
(0.078)\end{array}$ & $\begin{array}{l}-0.655^{* * *} \\
(0.074)\end{array}$ & $\begin{array}{l}0.107^{* * *} \\
(0.033)\end{array}$ & 78.691 \\
\hline Spain & $\begin{array}{l}-0.022 \\
(0.050)\end{array}$ & $\begin{array}{l}-0.656^{* * *} \\
(0.074)\end{array}$ & $\begin{array}{l}0.048 \\
(0.031)\end{array}$ & 78.664 \\
\hline Sweden & $\begin{array}{l}0.120^{*} \\
(0.072)\end{array}$ & $\begin{array}{l}-0.656^{* * *} \\
(0.074)\end{array}$ & $\begin{array}{l}0.136^{* * *} \\
(0.027)\end{array}$ & 78.664 \\
\hline United Kingdom & $\begin{array}{l}-0.021 \\
(0.042)\end{array}$ & $\begin{array}{l}-0.655^{* * *} \\
(0.074)\end{array}$ & $\begin{array}{l}0.093^{* * *} \\
(0.027)\end{array}$ & 78.691 \\
\hline
\end{tabular}

Table 5: Bila,teral response

Notes: An observation is a recipient and a year. Standard errors bootstrapped and clustered at the recipient and year level. Controls as column (4) of table $2 . * * * p<0.01, * * p<0.05, * p<0.1$ 
Specification

(1) Baseline estimates

(2) All donors

(3) Donors at least 10 years

(4) Donors at least 20 years

(5) EU and European donors together

(6) $1988-2005$

(7) $1988-2001$

(8) 1991-2001

(9) $1995-1997$

(10) W/o split and small countries

(11) EU food aid in 1995

(12) EU food aid between 1993 and 1995

(13) Excluding emergency food aid
2SLS Estimates Sd.Err. First stage Sd. Err. Obs (K-P. F-Stat)

$0.056^{* *}$

Changes in sample definition

Donors

\begin{tabular}{ccccr}
$0.008^{* * *}$ & $(0.002)$ & $-0.661^{* * *}$ & $(0.072)$ & $227235(84.270)$ \\
$0.033^{* * *}$ & $(0.005)$ & $-0.661^{* * *}$ & $(0.072)$ & $69808(85.017)$ \\
$0.072^{* * *}$ & $(0.013)$ & $-0.661^{* * *}$ & $(0.072)$ & $32052(84.750)$ \\
$0.125^{* * *}$ & $(0.004)$ & $-0.296^{* * *}$ & $(0.076)$ & $21770(15.051)$ \\
& \multicolumn{5}{c}{ Period } \\
$0.046^{*}$ & $(0.026)$ & $-0.506^{* * *}$ & $(0.083)$ & $15326(53.750)$ \\
$0.063^{*}$ & $(0.036)$ & $-0.425^{* * *}$ & $(0.098)$ & $11263(27.972)$ \\
$0.063^{*}$ & $(0.038)$ & $-0.414^{* * *}$ & $(0.102)$ & $9775(26.853)$ \\
-0.089 & $(0.190)$ & -0.146 & $(0.106)$ & $3671(5.479)$ \\
\multicolumn{5}{c}{ Recipients } \\
$0.088^{* * *}$ & $(0.015)$ & $-0.518^{* * *}$ & $(0.074)$ & $17967(68.440)$
\end{tabular}

Changes in the definition of $\mathbf{P}_{r}$

$\begin{array}{rllll}0.002 & (0.029) & -0.360^{* * *} & (0.098) & 21754(13.431) \\ 0.057^{* *} & (0.022) & -0.651^{* * *} & (0.075) & 21754(75.197) \\ 0.059^{* * *} & (0.018) & -0.489^{* * *} & (0.072) & 21770(45.920)\end{array}$

Table 6: Robustness checks

Notes: Row (1) refers to estimates obtained in column (4) in table 2. Except for rows (2) to (4) donors are non EU members donors. Standard errors bootstrapped and clustered at the recipient and year level in parenthesis. $* * * p<0.01, * * p<0.05, * p<0.1$ 


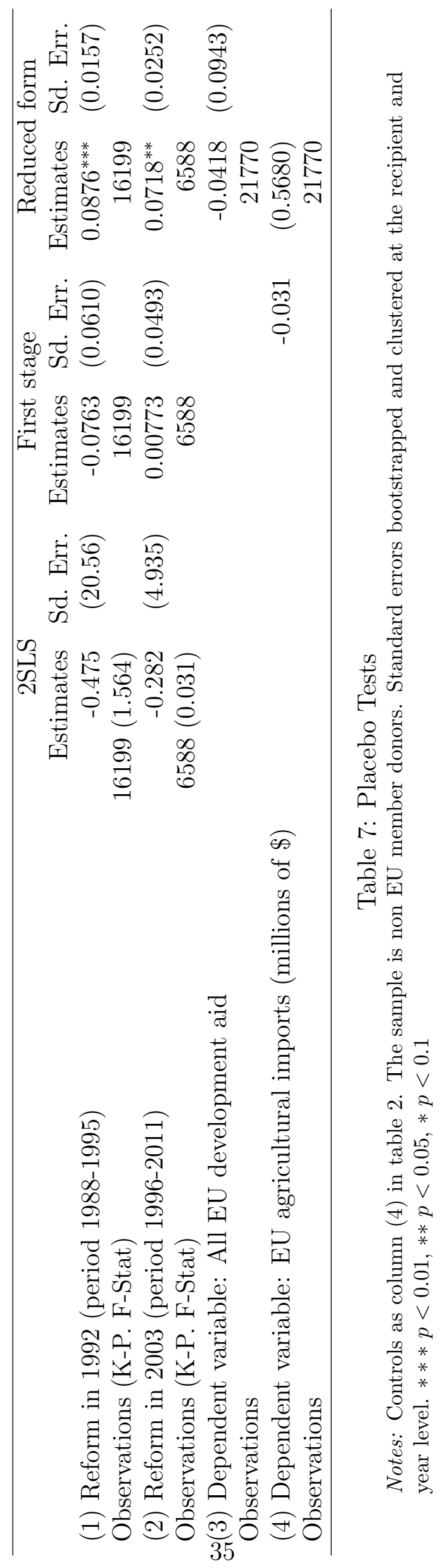




\section{A DESCRIPTIVE STATISTICS}

Figure A.1 provides the annual average quantities received by EU recipients. Table A.1 provides descriptive statistics on control variables.

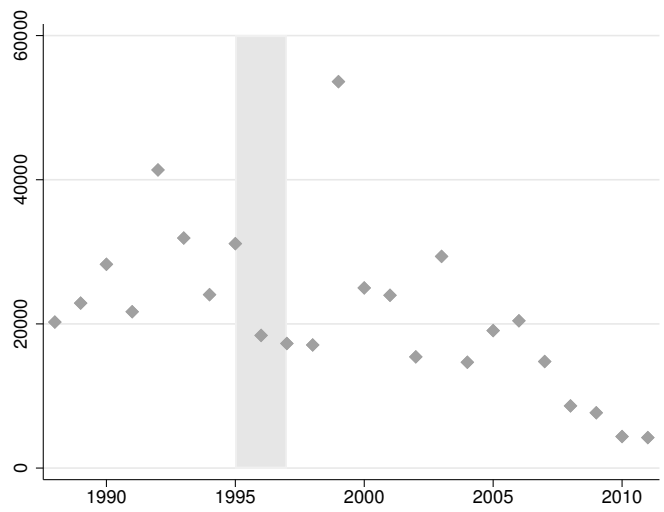

Figure A.1: Average quantity received from the EU by EU recipient countries (in metric tons) 


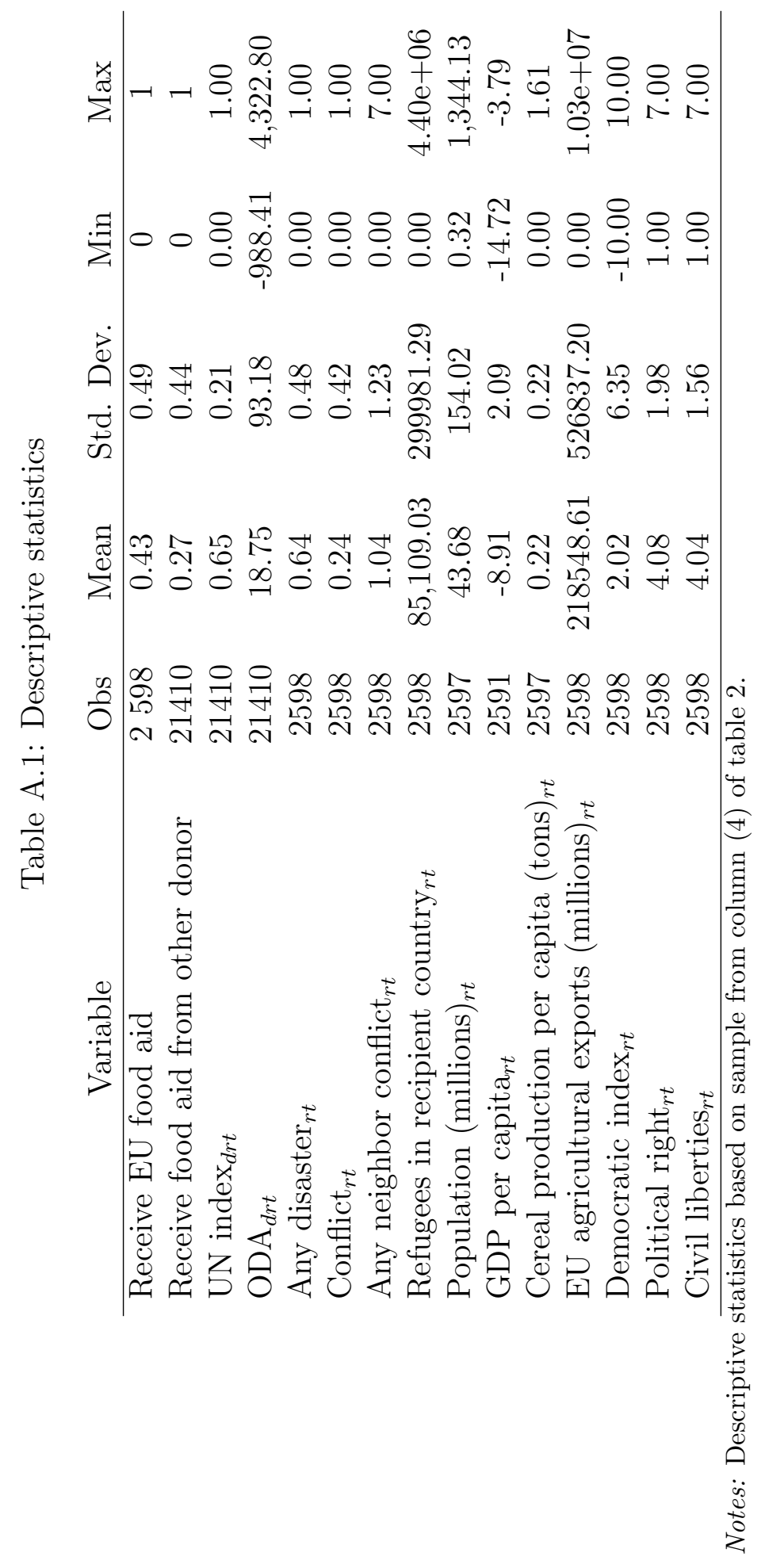




\section{B ADDITIONAL RESULTS}

Table B.1 gives pre-trend analysis for EU food aid allocation depending on the type of recipients.

Table B.1: Pre-trend analysis

\begin{tabular}{rccc}
\hline \multicolumn{5}{c}{ Has received food aid from the EU } \\
& $(1)$ & $(2)$ & $(3)$ \\
Recipients & All & Small & Large \\
\hline $\mathrm{P}_{r}$ interacted with & & & \\
Year 1990 & 0.053 & -0.253 & 0.107 \\
& $(0.078)$ & $(0.194)$ & $(0.102)$ \\
Year 1991 & -0.063 & -0.113 & -0.090 \\
& $(0.101)$ & $(0.124)$ & $(0.140)$ \\
Year 1992 & -0.019 & 0.003 & -0.023 \\
& $(0.090)$ & $(0.113)$ & $(0.122)$ \\
Year 1993 & 0.024 & -0.133 & 0.039 \\
& $(0.083)$ & $(0.162)$ & $(0.105)$ \\
Year 1994 & -0.022 & -0.050 & -0.001 \\
& $(0.093)$ & $(0.167)$ & $(0.118)$ \\
Year 1995 & -0.001 & 0.073 & 0.012 \\
& $(0.088)$ & $(0.136)$ & $(0.107)$ \\
Observations & 715 & 119 & 596 \\
$\mathrm{R}^{2}$ & 0.022 & 0.045 & 0.037 \\
Year FE & Yes & Yes & Yes \\
Recipient FE & Yes & Yes & Yes \\
Observations & 751 & 119 & 596 \\
R-squared & 0.061 & 0.280 & 0.084 \\
Recipients & 119 & 18 & 101
\end{tabular}

Notes: One observation is a recipient and year. Standard errors clustered at the recipient and year level. $P_{r}$ is the average probability of receiving food aid from the EU before 1996. Regressions include controls from column (4) of table 2. Reference year 1988. Year 1989 interacted with $P_{r}$ is dropped due to collinearity. $* * * p<0.01, * * p<0.05, * p<0.1$. 